Joshua J. F. Coutts

\title{
The Divine Name in the Gospel of John
}

\author{
Significance and Impetus
}

[Der göttliche Name im Johannesevangelium. Bedeutung und Anstoß.]

Veröffentlicht auf Englisch.

Eine der charakteristischen Eigenschaften des vierten Evangeliums ist die Bedeutung, die es dem »Namen« (óvo $\mu \alpha)$ Gottes beimisst. Da bereits die frühesten christlichen Texte eine Verlagerung des Namens Jesu zu einem kultischen oder göttlichen Namen aufweisen, stellt sich die Frage, was den Evangelisten dazu gebracht haben könnte, die Kategorie des göttlichen Namens wiederzubeleben. Joshua J. F. Coutts zeigt, dass der göttliche Name dadurch besondere Bedeutung erlangte, wie der Evangelist Jesaja las, was, in Verbindung mit der polemischen Erfahrung und den seelsorgerischen Bedürfnissen früher Christen, der Auslöser für sein Interesse am göttlichen Namen war.

The Divine Name in the Gospel of John

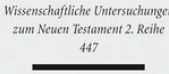

Mohr Siebeck

2017. XVI, 259 Seiten. WUNT II 447

ISBN 978-3-16-155612-8

DOI 10.1628/978-3-16-155612-8

eBook PDF $94,00 €$

ISBN 978-3-16-155188-8

fadengeheftete Broschur 94,00€
Joshua J. F. Coutts Born 1983; 2006 BA in Theology (Briercrest College); 2011 MCS (Biblical Studies concentration) (Regent College); 2016 PhD in New Testament Language, Literature, and Theology (University of Edinburgh); currently Lecturer in New Testament at Regent College, Vancouver.

\section{Jetzt bestellen:}

https://mohrsiebeck.com/buch/the-divine-name-in-the-gospel-of-john-9783161556128?no_cache=1 order@mohrsiebeck.com

Telefon: $+49(0) 7071-923-17$

Telefax: $+49(0) 7071-51104$ 